\title{
Factors of Variation of Soil Chemical Properties in Metalliferous Ecosystems of Tenke-Fungurume, Katanga, Democratic Republic of the Congo
}

D. Kaya Muyumba, E. Ilunga wa Ilunga, M.-P. Faucon, G. Mahy, A. Liénard, M. Séleck, M. Ngongo Luhembwe \& G. Colinet

D. Kaya Muyumba : Congolese R.D., MSc., Researcher, University of Lubumbashi, Faculty of Agronomy, Lubumbashi, Democratic Republic of the Congo. University Liège, Gembloux Agro-Bio Tech, BIOSystem Engineering, Water-Soil-Plant exchanges, Gembloux, Belgium.

E. Ilunga wa Ilunga : Congolese R.D., PhD, Professor, University of Lubumbashi, Faculty of Agronomy, Lubumbashi, Democratic Republic of the Congo. ${ }^{4}$ Université de Liège, Gembloux AgroBio Tech, BIOSystem Engineering, Biodiversity and Landscape Unit, Gembloux, Belgium.

M.-P. Faucon : French, PhD, Professor, Institut Polytechnique UniLaSalle, AGHYLE, UP.2018.C101, SFR Condorcet FR CNRS 3417, Beauvais, France.

G. Mahy : Belgian, PhD, Professor,Université de Liège, Gembloux Agro-Bio Tech, Biodiversity and Landscape Unit, Gembloux, Belgium

A. Liénard : Belgian, PhD, Researcher,University Liège, Gembloux Agro-Bio Tech, Water-SoilPlant exchanges, Gembloux, Belgium.

M. Séleck : Belgian, Ir, Researcher, Université de Liège, Gembloux Agro-Bio Tech, Biodiversity and Landscape Unit, Gembloux, Belgium

M. Ngongo Luhembwe : Congolese R.D., PhD, Professor, University of Lubumbashi, Faculty of Agronomy, Lubumbashi, Democratic Republic of the Congo.

G. Colinet : Belgian, PhD, Professor, University Liège, Gembloux Agro-Bio Tech, Water-Soil-Plant exchanges, Gembloux, Belgium. Email: Gilles.Colinet@ulg.ac.be.

Received on 29.01.18 and accepted for publication on 02.09.18.

DOI: $\underline{10.25518 / 2295-8010.250}$

Résumé :

Facteurs de variation des propriétés physico-chimiques des sols des écosystèmes métallifères de Tenke-Fungurume, Katanga, République Démocratique du Congo

Cette étude a pour objet les relations entre propriétés des sols et distribution des unités de végétation dans les écosystèmes métallifères de Tenke-Fungurume au Katanga en République Démocratique du Congo. La première question étudiée visait l'estimation des différences et similitudes entre sols des principales unités de végétation. La caractérisation des sols a permis 
d'identifier, par analyse multivariée, quatre facteurs de variation des propriétés physicochimiques des sols qui sont tous liés à la lithologie. Nos résultats suggèrent que la variabilité observée entre unités de végétation (savane steppique enrochée, pelouse et savanes steppiques de pente ou de Dembo) est partiellement liée aux différences de composition géochimique des matériaux parentaux entre les sites mais également et principalement due à une variabilité importante du fond géochimique au sein de chaque unité de végétation. Les contaminations des sols en $\mathrm{Cu}$ et Co proviennent de l'altération des roches et la variabilité des teneurs mesurées au sein des unités de végétation peut aussi bien résulter de la variabilité des matériaux parentaux que des processus d'érosion.

La deuxième question visait l'étude des transitions entre unités de végétation à l'échelle métrique. Les changements abrupts de végétation ont été clairement mis en parallèle avec des modifications des propriétés des sols, en lien avec la lithologie encore une fois. La clef de la distribution de ces unités est la disponibilité du cuivre.

\section{Abstract :}

Our study aimed at deepen our understanding of relationships between soil properties and vegetation distribution in metalliferous ecosystems of Tenke-Fungurume in the Democratic Republic of Congo. The first question concerned the differences and similarities between soils of the main vegetation units and four variation factors of soil properties were summarized by multivariate analysis. They were all linked to lithology and significantly contributed to explain the distribution of vegetation units. Our result suggest that the variation of soil properties which is observed within the various vegetation units (rocky steppe savanna, sward, and steppe savannas on slope or on Dembo) should partially be attributed to differences of geochemical composition of rocks between sites but the main source of variability is to be found inside each hill. The soil contamination in $\mathrm{Cu}$ and $\mathrm{Co}$ originates from rock weathering and besides site effect and topographic distribution of the rocks, the variability of soil properties within one vegetation unit may be due to variability of soil parent material and not only to erosion.

The second question dealt with the changes of soil properties at small distances. Metric variation was studied from transects between adjacent vegetation units. Our results showed that the abrupt changes of vegetation units which were clearly identified on the field were all truly explained by the variations of one or more properties linked to lithology. The key point being the $\mathrm{Cu}$ bioavailability.

Keywords : cobalt, copper, D. R. Congo, metalliferous hills, soil properties, vegetation units

\section{Introduction}

Metal-rich soils provide very restrictive habitats for plants due to phytotoxicity and resulting severe selection pressure (1). They can host a unique flora (12), such as copper flora from which plant species contribute highly to global biodiversity (20) and are priceless related to their properties $(44,49)$. Primary calamine and serpentinic sites are other examples of sites on which metal-specific vegetation develops $(23,50)$.

Soil enrichment in copper $(\mathrm{Cu})$ and cobalt (Co) may result from natural anomalies or human activities (21). In soils, metals from natural origin are generally less mobile than anthropogenic one $(16,21,37)$. 
Indeed, copper and cobalt are nutrients to living organisms when they are at low concentrations $(26,38,47)$ and become toxic at high concentrations $(11,47)$. Excess of $\mathrm{Cu}$ induces injuries to plants by generating oxidative stress and reactive oxygen species while Co adversely affects shoot growth and biomass (36). However, some plants are able to tolerate high concentrations of $\mathrm{Cu}$ and $\mathrm{Co}$ in soils $(2,6)$. Tolerance mechanisms to $\mathrm{Cu}$ and $\mathrm{Co}$ were found on some cuprophytes from Katanga $(4,7,8,10,34,35,39)$.

In Katanga province, mineralized rocks rich in $\mathrm{Cu}$ and Co outcrop at the summit of hills which they protect against erosion. The concentrations of these two elements can reach up to a few tens of thousands of mg.kg ${ }^{-1}$ in soils $(9,24,25,28)$. Saad et al. (43) reported total Cu concentrations between 100 and more than 35,000 mg/kg. On these metalliferous outcrops, grows an original flora composed of at least 600 species of plants, of which 33 were recognized as strictly endemic to this environment (13). These species are distributed in the landscape within plant communities, called further as vegetation units. Mineralized particles are redistributed along the slope by erosion. These phenomena generate a gradient of $\mathrm{Cu}$ and Co concentrations in the topsoil that directly affects the distribution of native vegetation $(9,28)$.

Mining activities lead to the destruction of the primary plant communities covering the outcrops and the surrounding soils and contribute to the total or partial loss of the species composing them. The protection of plant biodiversity in this specific context relies on ex-situ conservation of threatened species and requires knowledge of their biotic and abiotic requirements for growing $(12,18)$.

The importance of soil properties to plant growth in reclaimed soils was reviewed by Sheoran et al. (45). Some key soil properties (acidity-basicity and redox potential) and soil constituents (clays, oxides and hydroxides of $\mathrm{Fe}, \mathrm{Mn}$ and $\mathrm{Al}$; carbonates, phosphates, organic matter) govern the behavior of trace elements in soils $(21,29,42)$. The availability of nutrients as well as changes in soil physical properties can both contribute to the differential distribution of plants within ecosystems. The change in plants communities in copper hills of Katanga was for a long time attributed only to $\mathrm{Cu}$ and $\mathrm{Co}$ in topsoils $(5,9,28,30)$. However, recent studies suggested that this variation would be also explained by the combination of edaphic factors other than trace metals concentration, such as nutrient and water availability or physical constraints $(12,19,43,44)$.

This combination of factors constitutes an edaphic gradient which influences the vegetation structure and would be at the origin of ecosystem complexity (44). The variation in edaphic factors can generate highly heterogeneous environment and promote a high diversity of plant assemblage over limited areas. At the top, chasmophytic vegetation generally develops on poorly mineralized rocks (i.e., plant communities colonising the cracks and fissures of low mineralised rock with $\mathrm{Cu}$ concentrations of 250-900 mg kg${ }^{-1}$ ). Steppe vegetation colonises the upper part of the outcrops with the highest $\mathrm{Cu}$ soil concentrations. Finally, steppic savannah vegetation develops on the intermediate and foothill slopes and flat periodically flooded savannahs (dembos) at the bottom of the outcrops with $\mathrm{Cu}$ concentrations varying from 100 to $3,500 \mathrm{mg} \mathrm{kg}^{-1}(9,43)$. Séleck et al. (44) found that site effect on plant diversity at local scale (differences between 3 neighbour hills) was significant. The random nature or site physically driven origin of this diversity was still open to debates. Effects of edaphic variation on vegetation structuration within site could be better understood if variation of soil properties at small distances, i.e. the transitions between two adjacent vegetation units, were examined.

The objective of this study was to deepen the relationship between soil properties and the 
Factors of Variation of Soil Chemical Properties in Metalliferous Ecosystems ...

vegetation units they support in the natural $\mathrm{Cu}$ and $\mathrm{Co}$ outcrops of the Tenke-Fungurume complex. We intended to examine the diversity of edaphic conditions for given plant communities within and between sites in order to gain objective elements for restoration strategies. Especially, the missing scale of investigation in previous studies is the metric variation between two adjacent vegetation units. To achieve this, two questions were developed:

1. What are the differences and similarities between soils of the four main vegetation units encountered from top to bottom of the hills?

2. Are the scales of variation of soil properties and vegetation units congruent for small distances?

\section{Materials and methods}

\section{Study area}

The study area is located in the region between the cities of Tenke and Fungurume, in the Southeast of D.R. Congo $\left(10.61^{\circ} \mathrm{S}, 26.20^{\circ} \mathrm{E}\right.$; altitude around 1,300 m). The climate is humid subtropical of CW6 type according to the Köppen classification (18), with a rainy and a dry season, from November to March and from May to September, respectively. Rainfalls are around $1300 \mathrm{~mm}$ and annual average temperature around $20^{\circ} \mathrm{C}$. The dominant vegetation of southeastern DR Congo is the Miombo woodland characterized by a predominance of Brachystegia, Julbernadia and Isoberlinia species. Copper hills present distinct feature from surroundings Miombo as clearings remarkable by their herbaceous vegetation (31).

The region hosts more than 40 copper outcrops (44). The geology is largely influenced by the RAT and the Mines Series, the latter being the most mineralized zone of the Roan Group $(15,22)$. The rocks within these series include, from youngest to oldest, calcareous rock with dark minerals $(\mathrm{CMN})$, dolomitic shales and schists (SDS, SDB), cellular or foliated siliceous rocks (RSC, RSF), stratified dolomites (D-Strat), and talcose argillaceous rocks (RAT) $(24,25,44)$. The siliceous rocks make up the backbone of the hilly landscape due to higher resistance to erosion processes.

\section{Soil sampling}

To answer the first question, fifty-seven samples of surface soils $(0-10 \mathrm{~cm})$ from the main vegetation units of Fungurume copper-cobalt deposits have been sampled within a list of 300 floristic 1-square meter observation plots in the 13 metalliferous hills of Tenke-Fungurume complex (18).

The main vegetation units in the sites were characterized upon a physiognomic approach according to Duvigneaud \& Denayer-De Smet (9) and Leteinturier (28) determinism. The following main vegetation units have been the subject of this study: the rocky steppic savanna (A) [mainly located on the topsoil over cellular siliceous rock (RSC)], sward (B) [mainly localized on very rich Cu and Co substrates], the slope steppic savanna (C) [usually on downstream slopes after sward] and the Dembo steppic savanna (D) [at the foot of the hill on deep soils]. Other components of the C and D units to burned state ( $\mathrm{Ci}$ and $\mathrm{Di}$ ) were considered in the transects.

Soil samples were obtained by mixing 4 cores taken at the corners of the one square-meter quadrat to a depth of $10 \mathrm{~cm}$. Only six of the thirteen hills were considered for this study namely: 
Fungurume-1 (Fu1), Fungurume-3 (Fu3), Fungurume-8 (Fu8), Fungurume-9 (Fu9), Shadiranzorocentral (SHC) and Shadiranzoro West (SHW). Soils were sampled according to the presence and the relative importance of each vegetation unit on the selected hills. The same approach was used on other hills of the same complex by other authors: Apostolo, Goma1, Kabwelunono, Kavifwafwaulu, Kwatebala, Shimbidi (43), Fungurume-5, Kazinayanga, Kavifwafwaulu (44).

To answer the second question, five short-distance transects across neighbouring vegetation units as identified on the field have been sampled. This part of the study aimed to assess whether the physiognomic sudden change observed on vegetation was parallel to similar sudden changes of soil physicochemical properties (Table 1). One of the transects was located at the top of Fungurume-3 (Fu3T), two on Fungurume-5 (Fu5T1 and Fu5T2) and the two others on Fungurume-8 (Fu8T1 and Fu8T2). The FuT3 transect (Figure 1) included six samples and crossed the limit between a rocky steppic savanna (A) and a Xerophyta sward (E - Figure 1). The Fu5T1 and Fu5T2 were respectively transects perpendicular and parallel to the slope direction. The first one crossed three vegetation units: a colluvium sward (B), a steppic savanna (C) and a forested vegetation with Uapaca sp. (I Figure 1). The Fu8T1 and Fu8T2 transects were both perpendicular to the slope direction. Fu8T1 was located on the upper slope of the eastern side hill while Fu8T2 (Figure 1) was located at the foot of the hill on the dembo plain. The vegetation units were two steppic savanna $(\mathrm{C}$ and $\mathrm{Ci})$ surrounding a colluvium sward (B) for Fu8T1 and two dembo steppic savanna (D, Di) alternating with one colluvium sward (B) and one Uapaca forest (I) on Fu8T2. Each transect targeted transitions between two (Fu3T) to four (Fu8T2) adjacent vegetation units, mainly organised across the slope, except Fu5T2 which was sampled along the slope. The origin of the presence of the vegetation units was supposed to be natural in most cases but the swards in Fu8 did show evidences of former basic activities of digging of small holes and galleries for ore extraction. Moreover, we distinguished among the vegetation units those which were recently burned from those which did not burn.

Table 1. List and characteristics of studied transects: vegetation units, symbols (see figure 1) and rock type

\begin{tabular}{lllll}
\hline Site & Transect & Vegetation units & Symbol* & Rock** \\
\hline Fungurume-3 & Fu3T & Xerophyta sp natural sward & (E) & RSF \\
\hline Fungurume-5 & & Rocky steppic savanna & (A) & RSC \\
\hline & Fu5T1 & Sward on colluvium & (B) & RAT \\
\hline & & Steppic savanna on slope & (C) & SDS/SDB \\
\hline & Eupacarobynsii grove & (I) & SDS/SDB \\
\hline & & Xerophita sp natural sward & (E) & RSF \\
\hline Fungurume-8 & Sward on colluvium & (B) & RAT \\
\hline & Steppic savanna on slope & (C) & RAT \\
\hline & Steppic savanna on slope (burned) & (Ci) & RAT \\
\hline & Sward on disturbed soil & (B) & RAT \\
\hline & Steppic savanna on slope & (C) & RAT \\
\hline & Fu8T2 & Dembo steppic savanna & (D) & deepsoil \\
\hline & Sward on colluvium & (B) & deepsoil \\
\hline & Dembo steppic savanna (burned) & deepsoil \\
\hline & Uapaca robynsii grove & (I) & deepsoil \\
\hline
\end{tabular}

* The symbols used correspond to Duvigneaud \& Denayer - De Smet (1963); Ci and Di are burned variants of $\mathrm{C}$ and $\mathrm{D}$ units respectively. 
Factors of Variation of Soil Chemical Properties in Metalliferous Ecosystems ...

** See legend in the text.
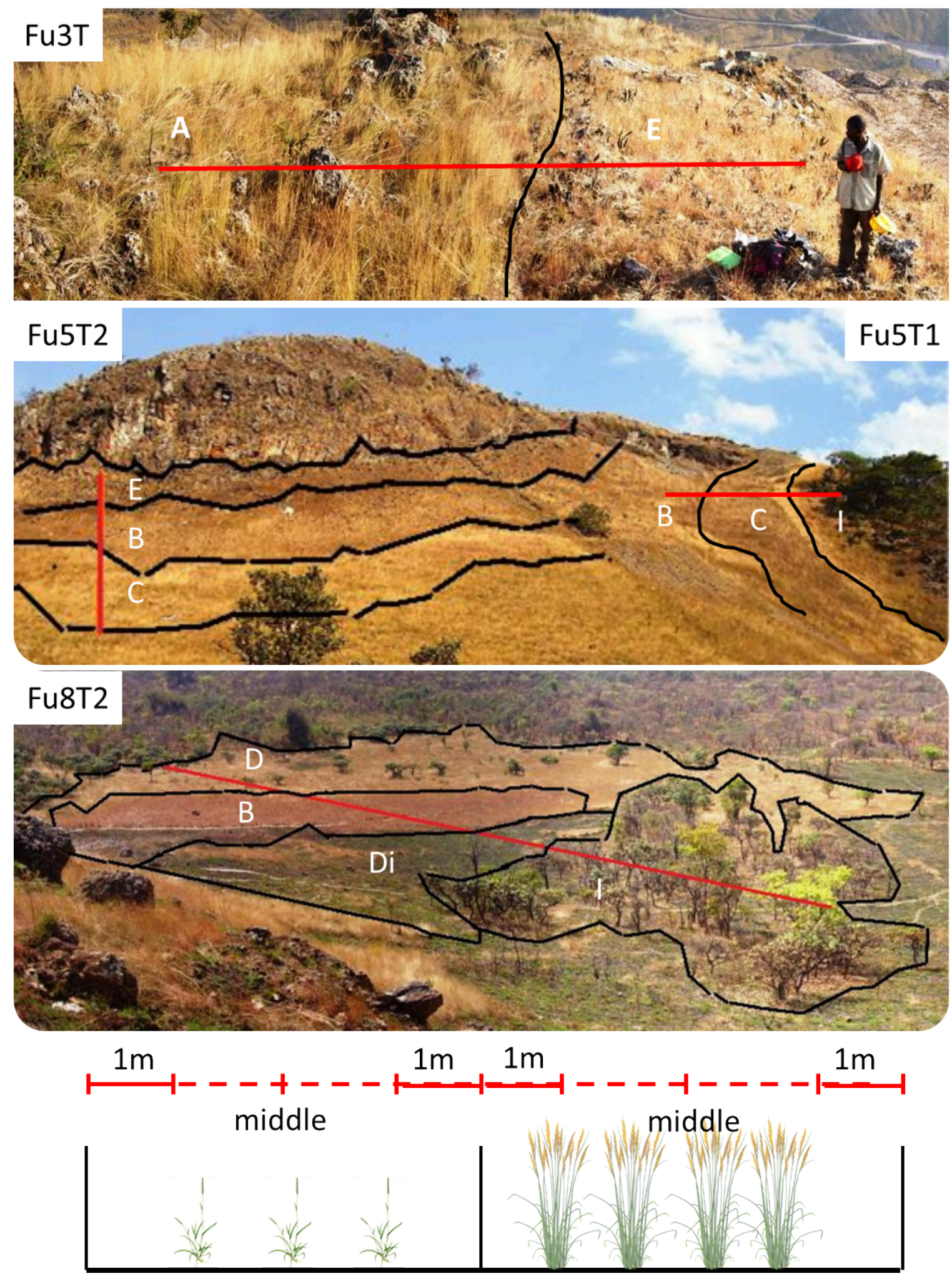

Figure 1: View over four of the five mini-transects carried out to evaluate the short scale changes in soil characteristics observed in adjacent vegetation units. 
See legend in table 1 . Soil samples were taken at $1 \mathrm{~m}$ of both ends of vegetation units along the transects and in the middle.

\section{Soil analysis}

All soil samples were dried at open air inside a room for 8 days and then passed through a $2 \mathrm{~mm}$ sieve. The $\mathrm{pH}$ was determined by mixing $2 \mathrm{~g}$ of soil with $50 \mathrm{ml}$ of distilled water and/or $1 \mathrm{~N} \mathrm{KCl}$. The mixture was stirred for 2 hours on a rotary device and centrifuged for 10 minutes at 3,000 rev/ min. Measurement was performed with a $\mathrm{pH}$ meter. Total organic carbon was measured by titration after wet oxidation with $\mathrm{K}_{2} \mathrm{Cr}_{2} \mathrm{O}_{7}$, according to the Walkley \& Black method (48).

Available cations ( $\mathrm{K}, \mathrm{Mg}, \mathrm{Ca}, \mathrm{P}, \mathrm{Cu}, \mathrm{Co}$, and $\mathrm{Mn}$ ) were extracted with EDTA $+\mathrm{CH}_{3} \mathrm{COONH}_{4}$ at $\mathrm{pH} 4.65$ (27). Total concentrations of elements were obtained by a digestion of $0.5 \mathrm{mg}$ of soil with a mixture of three acids namely: $2 \mathrm{ml} \mathrm{HNO}_{3}+1 \mathrm{ml} \mathrm{HClO}_{4}+5 \mathrm{ml} \mathrm{HF}$ according to AFNOR 1996:NF X31-147. Total contents $(\mathrm{Cu}, \mathrm{Co}, \mathrm{Al}, \mathrm{Fe}, \mathrm{Mn})$ were only measured on transect samples. The determination of $\mathrm{Al}, \mathrm{Fe}$ and $\mathrm{Mn}$ aimed at characterizing the general soil properties, especially they express the mineralogical signature of rocks $(15,22)$ and $\mathrm{Al}$ and Fe may be used as proxies of soil texture $(29)$. Soluble metals $(\mathrm{Cu}, \mathrm{Co})$ were obtained by extraction with $0.01 \mathrm{M} \mathrm{CaCl}_{2}(17)$. This is considered as labile or mobile fraction $(33,46)$ in soils. Measurement of total, available and soluble metals have been made by flame atomic absorption spectrometry (VARIAN model 220).

\section{Statistics}

Factorial analysis was performed from Principal Component Analysis (PCA) with varimax rotation in order to identify the underlying factors of variability among the studied soil properties. Analysis of variance was used in order to test the significance of "Site" and "Vegetation" factors in the first analysis, and of differences between vegetation units in the study of transects. Soil characteristics were transformed, except for $\mathrm{pH}$, in order to approach normality and homoscedasticity. Transformations were square-root for TOC and $\log _{10}$ for all other parameters. A General Linear Model (GLM) was used in the comparison of sites and vegetation units because of unbalanced design: The Dembo steppic savanna (D) was only present in Fu1 and Fu8, the rocky steppic savanna (A) was absent from SHW, and the colluvium sward (B) absent from Fu9. The interactions between "Site" and "Vegetation" were tested separately according to the associations. Results indicated the absence of significant interactions and factors could be analysed at once.

One-way ANOVA and Tukey test at $p 0.05$ were used to analyse the variability of soil properties in the transects. The fifteen properties were tested after transformation accepted for $\mathrm{pH}$ and total $\mathrm{Mn}, \mathrm{Al}$ and $\mathrm{Fe}$. The available Co was not measured. Additionally, the variation of properties between pairs of neighbouring points inside vegetation units was compared to that of neighbours at both sides of the limit between two vegetation units. The indicator of variation was the semi-variance, which use is frequent in geostatistics (Equation I). 


$$
\gamma(h)=\frac{1}{2 N(h)} \sum_{\alpha=1}^{N(h)}\left[z\left(u_{\alpha}+h\right)-z\left(u_{\alpha}\right)\right]^{2}
$$

\section{(I)}

where $z\left(u_{\alpha}\right)$ and $z\left(u_{\alpha}+h\right)$ are the values of the variable under consideration at the two locations separated by a distance $h$. The distances $h$ were fixed at 2 and 10 meters in order to discriminate the variations of neighbouring points between and within vegetation units. $N_{(h)}$ is the number of pairs for the given distance $h$.

In the semivariance analysis, the "within-unit" estimates the variance with the closest point within the same unit while the "between-unit" relates to differences across the limit between two vegetation units. Semivariance was also compared to variance within vegetation units, which was estimated by the residual mean square in the ANOVA.

The software used for statistical analysis were Minitab 17 and R.

\section{Results}

\section{Soil properties under main vegetation units of the studied hills}

As stated previously, the interactions between the types of vegetation and the sites were considered as non-significant for most parameters. The only exception to this was the case of $\mathrm{Cu}_{\mathrm{CaCl}}$ when comparing differences of A, B, C, D vegetation units between Fungurume 1 and 8 (the only two hills presenting all the 4 vegetation units). The $p$-value for interactions was 0.015 , due to the fact that $\mathrm{B}$ and $\mathrm{C}$ units showed lower content in Fu8 compared to Fu1. Nevertheless, we performed analysis of the GLM without interactions and analysed the effects of factors independently.

The means and standard variations of soil chemical characteristics are given in table 2, according to the sites and vegetation units. It should be reminded that if untransformed data are presented, analysis of variances and p-values concerned transformed data. It can be seen that the variations within sites are high according to the values of standard deviations. In some cases, the coefficients of variation are higher than $100 \%$, such as for $\mathrm{Cu}_{\mathrm{EDTA}}$ or $\mathrm{Cu}_{\mathrm{CaCl} 2}$. Another point to consider is the unbalanced design of samples which is linked to relative importance of the number of existing observations plots. The confidence intervals on the means for SHC and SHW could therefore be overestimated compared to the other sites due to these differences of number of observations.

Significant differences between sites were found for TOC, $\mathrm{Cu}_{\mathrm{EDTA}}, \mathrm{Cu}_{\mathrm{CaCl2}}$ and $\mathrm{Co}_{\mathrm{CaCl2}}$ at $p$-values $<0.001, \mathrm{Co}_{\mathrm{EDTA}}(p<0.01)$ and finally $\mathrm{P}_{\mathrm{EDTA}}$ and $\mathrm{Mn}_{\mathrm{EDTA}}(p<0.05)$. It should however be noted for the latter two elements that the Tukey test does not allow to identify one hill significantly different than another one. As can be seen in table 2 and figure 2, important differences were found between soil organic content of the sites. Especially, TOC content in SHC and Fu3 were bigger than in Fu1, 
Fu8 and Fu9. The pH and the major nutrient status, P excepted, were rather homogenous through the hills. The $\mathrm{Cu}$ and Co contents appeared as relatively discriminating properties of the chemical characteristics of the sites (Table 2, Figure 2). In particular, SHC, Fu1 and Fu3 show higher mean $\mathrm{Cu}$ content than the three other sites, while Fu9 is clearly the less contaminated of the study sites. Regarding Co content, Fu3 and Fu8 show the highest levels and SHC and SHW the lowest, which means that mineralization of rocks with $\mathrm{Cu}$ and $\mathrm{Co}$ might have differed from one site to another.

Regarding vegetation units (Table 2, Figure 2), eight of eleven parameters considered showed a significant difference $(p<0.05)$. Among them, $\mathrm{pH}_{\mathrm{KCl}}, \mathrm{Mg}, \mathrm{P}$, and $\mathrm{Cu}$ contents were the most significant $(p<0.001)$.

Table 2. Chemical characteristics of soils of quadrats under the main vegetation units and sites: TOC (\%), pH, K, Mg, Ca and P in mg/100 g, Cu, Co and $\mathrm{Mn}$ in mg/kg (means \pm standard deviations).

\begin{tabular}{|c|c|c|c|c|c|c|c|c|}
\hline \multirow{2}{*}{$\begin{array}{l}\text { Soil } \\
\text { parameters }\end{array}$} & \multicolumn{4}{|c|}{ Main vegetation units (see legend in the text) } & \multirow{2}{*}{$\mathrm{p}$} & \multicolumn{3}{|c|}{ Sites (see legend in the text) } \\
\hline & $\begin{array}{l}\text { A } \\
(n=11)\end{array}$ & $\begin{array}{l}\text { B } \\
(n=13)\end{array}$ & $\begin{array}{l}\text { C } \\
(n=28)\end{array}$ & $\begin{array}{l}\mathrm{D} \\
(n=4)\end{array}$ & & $\begin{array}{l}\text { Fu1 } \\
(\mathrm{n}=10)\end{array}$ & $\begin{array}{l}\text { Fu3 } \\
(\mathrm{n}=12)\end{array}$ & $\begin{array}{l}\text { Fu8 } \\
(n=13)\end{array}$ \\
\hline TOC & $2.9 \pm 1.8^{\mathrm{ab}}$ & $4.3 \pm 2.4^{\mathrm{a}}$ & $2.2 \pm 1.2^{\mathrm{b}}$ & $1.6 \pm 0.5^{\mathrm{ab}}$ & 0.009 & $2.4 \pm 1.6^{\mathrm{C}}$ & $4.0 \pm 1.8^{\mathrm{ab}}$ & $1.6 \pm 0.4^{\mathrm{C}}$ \\
\hline $\mathrm{pH}_{(\mathrm{KCl})}$ & $4.2 \pm 0.4^{\mathrm{b}}$ & $5.1 \pm 0.6^{\mathrm{a}}$ & $4.8 \pm 0.4^{\mathrm{a}}$ & $4.8 \pm 0.4^{\mathrm{ab}}$ & 0.000 & $4.8 \pm 0.6$ & $4.8 \pm 0.6$ & $4.9 \pm 0.6$ \\
\hline $\mathrm{K}$ & $6.4 \pm 0.94^{b}$ & $6.7 \pm 0.79^{b}$ & $10 \pm 0.56^{\mathrm{a}}$ & $11 \pm 1.5^{\mathrm{ab}}$ & 0.002 & $7.0 \pm 3.1$ & $7.2 \pm 3.2$ & $10.2 \pm 3.7$ \\
\hline $\mathrm{Mg}$ & $6.2 \pm 1.75^{\mathrm{b}}$ & $6.2 \pm 1.49^{b}$ & $13 \pm 1.05^{\mathrm{a}}$ & $13 \pm 2.78^{\mathrm{ab}}$ & 0.000 & $6.7 \pm 3.5$ & $10.0 \pm 7.3$ & $12.4 \pm 6.1$ \\
\hline $\mathrm{Ca}$ & $20 \pm 18$ & $18 \pm 14$ & $28 \pm 24$ & $26 \pm 6$ & 0.226 & $20 \pm 15$ & $28 \pm 27$ & $25 \pm 17$ \\
\hline $\mathrm{P}$ & $2.84 \pm 1.62^{b}$ & $6.58 \pm 4.02^{\mathrm{a}}$ & $1.73 \pm 1.76^{\mathrm{b}}$ & $1.13 \pm 0.21^{\mathrm{b}}$ & 0.030 & $2.72 \pm 1.73$ & $4.13 \pm 3.26$ & $3.15 \pm 4.37$ \\
\hline $\mathrm{Cu}_{(\mathrm{EDTA})}$ & $319 \pm 503^{c}$ & $4152 \pm 2968^{a}$ & $465 \pm 599^{b}$ & $368 \pm 143^{b c}$ & 0.000 & $2111 \pm 3372^{\mathrm{abc}}$ & $1598 \pm 1895^{\mathrm{ab}}$ & $646 \pm 1248^{\mathrm{cd}}$ \\
\hline $\mathrm{Cu}_{(\mathrm{CaCl} 2)}$ & $16 \pm 27^{b}$ & $116 \pm 75^{\mathrm{a}}$ & $12 \pm 19^{b}$ & $13 \pm 10^{b}$ & 0.000 & $63 \pm 80^{\mathrm{ab}}$ & $53 \pm 76^{\mathrm{a}}$ & $13 \pm 19^{b c}$ \\
\hline $\mathrm{Co}_{(\mathrm{EDTA})}$ & $17 \pm 18^{b}$ & $41 \pm 38^{\mathrm{a}}$ & $21 \pm 14^{\mathrm{ab}}$ & $16 \pm 13^{a b}$ & 0.042 & $20 \pm 33^{a b}$ & $33 \pm 22^{a}$ & $34 \pm 30^{\mathrm{a}}$ \\
\hline $\mathrm{Co}_{(\mathrm{CaCl} 2)}$ & $11 \pm 12$ & $19 \pm 21$ & $9.0 \pm 6.6$ & $8.2 \pm 7.5$ & 0.210 & $7.5 \pm 9.0^{\mathrm{abc}}$ & $16 \pm 12^{\mathrm{a}}$ & $17 \pm 19^{a}$ \\
\hline $\mathrm{Mn}_{\text {(EDTA) }}$ & $29 \pm 16^{b}$ & $44 \pm 30^{\mathrm{ab}}$ & $52 \pm 34^{\mathrm{a}}$ & $54 \pm 31^{a b}$ & 0.025 & $29 \pm 15$ & $45 \pm 20$ & $52 \pm 20$ \\
\hline
\end{tabular}

The analysis of variance was performed on log10-transformed data excepted for TOC (square root) and $\mathrm{pH}$ (no transformation). Interactions between factors were not significant. Means that do not share a letter are significantly different after Tukey at 95\%.

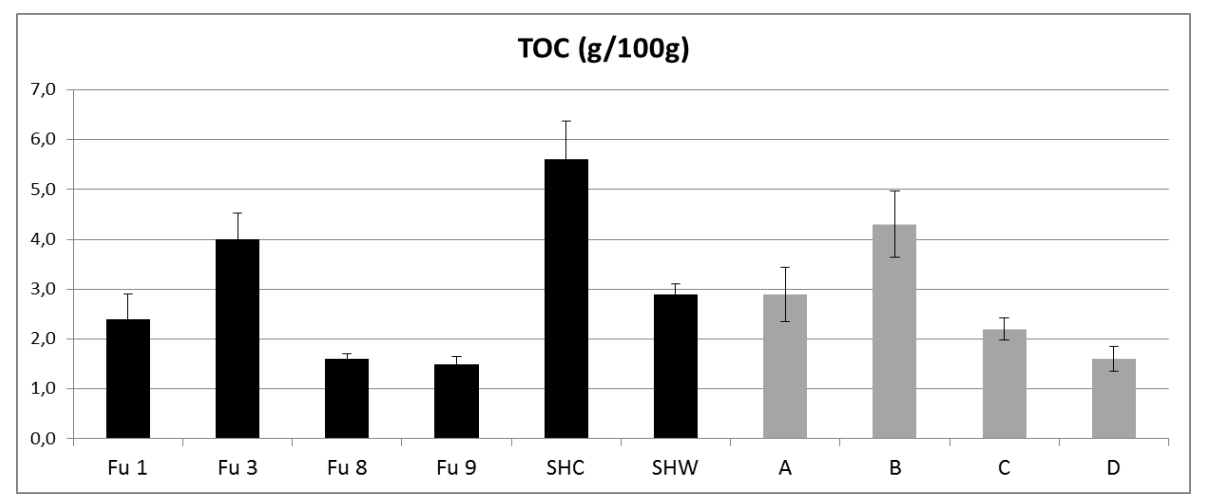



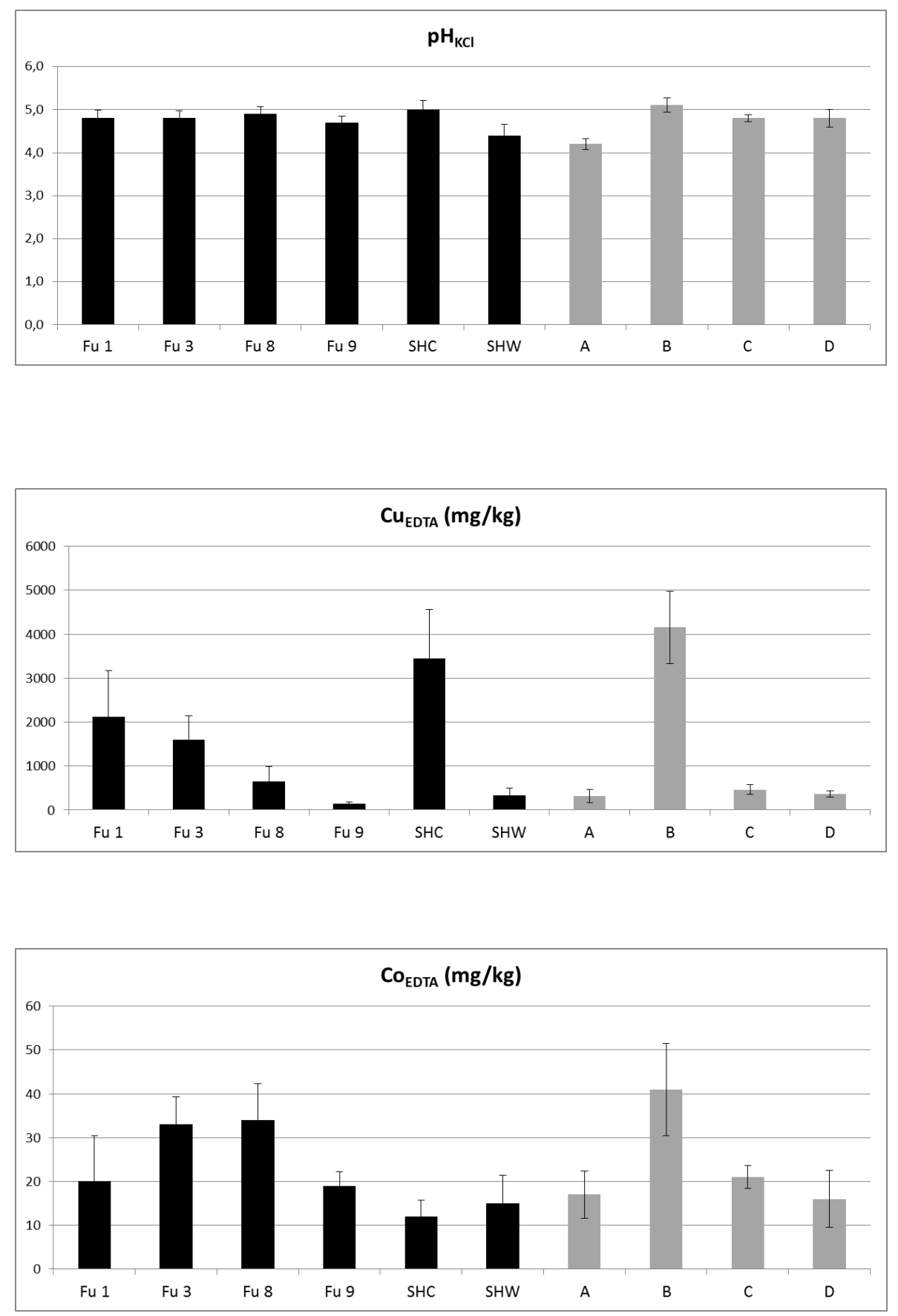

Figure 2: Variation of soil properties between sites and vegetation units (mean value and standard error): Total Organic Carbon, $\mathrm{pH}_{\mathrm{KCl}}$, available $\mathrm{Cu}$ and Co. Legend in text.

The comparison of vegetation units in table 2 showed that sward soils (B) presented the highest levels for TOC, $\mathrm{pH}_{\mathrm{KCl}}, \mathrm{P}, \mathrm{Cu}, \mathrm{Co}$ and $\mathrm{Mn}$. This unit presented also the lowest concentrations in $\mathrm{K}$, $\mathrm{Mg}$, and Ca. Compared to swards, the steppic savannas on slopes (C) and dembo (D) are the most different. Due to topographical position and nature of soil parent material (RAT), these units showed lower levels of $\mathrm{Cu}$-Co contamination and higher nutrient content, $\mathrm{P}$ excepted. Soils from rocky steppic savannas (A) were more acidic than those from sward and downslope steppic savannas, due to siliceous nature of parent material. Similarly, nutrient content is rather poor in A unit. 
The soil properties in metalliferous ecosystems of Katanga are usually significantly correlated and PCA analysis was used by several authors to identify edaphic factors $(14,43,44)$. We performed a factorial analysis from a PCA with varimax rotation on soil chemical properties. The figure 3 shows the results of the PCA before rotation. Four factors were kept as they make up more than $85 \%$ of total variance. These factors should be identified as:

1. a Cu-contamination factor,

2. the richness in major nutrients,

3. a Co-contamination factor different from the first one, and finally

4. an acidification factor.

The first factor, not only reflects the direct effect of contamination in $\mathrm{Cu}$ due to mineralized rock but it also shows lithological origin of $\mathrm{P}$ and indirect effect on the accumulation of organic matter probably due to a decrease of biological activity and decomposition processes. The second factor is clearly under the influence of major nutrients, P excepted, and Mn. Soils downslope developped on RAT are clearly richer in these elements and lithology seems to be a predominant factor of spatial distribution, even if downward redistributions with soil water fluxes cannot be discarded at this stage. The factor 3 constitutes another factor linked to contamination by the parent material, which also indicates differences of rock elemental composition between sites. Finally, the fourth factor is driven by $\mathrm{pH}_{\mathrm{KCl}}$, $\mathrm{Ca}$ and $\mathrm{Mg}$ content, which separates the rocky steppic savannas on siliceous rocks from the three other vegetation units, or SHW from the other hills, as they are more acidic.

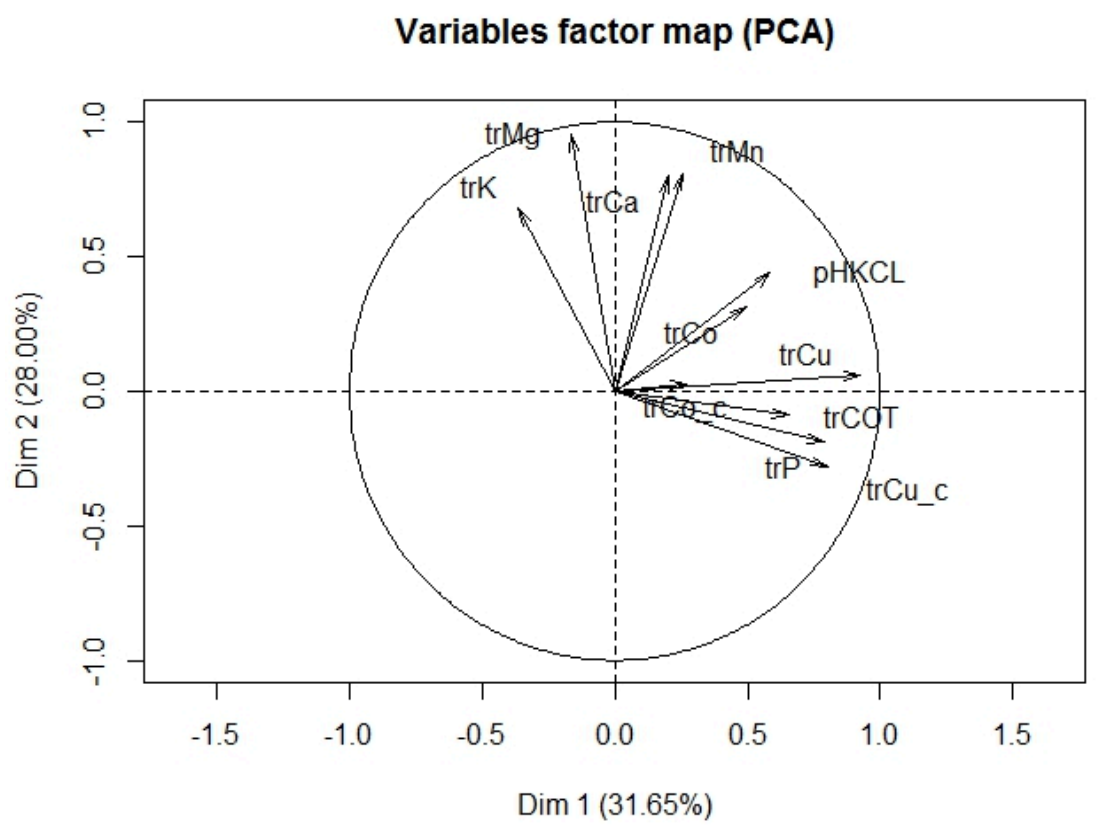




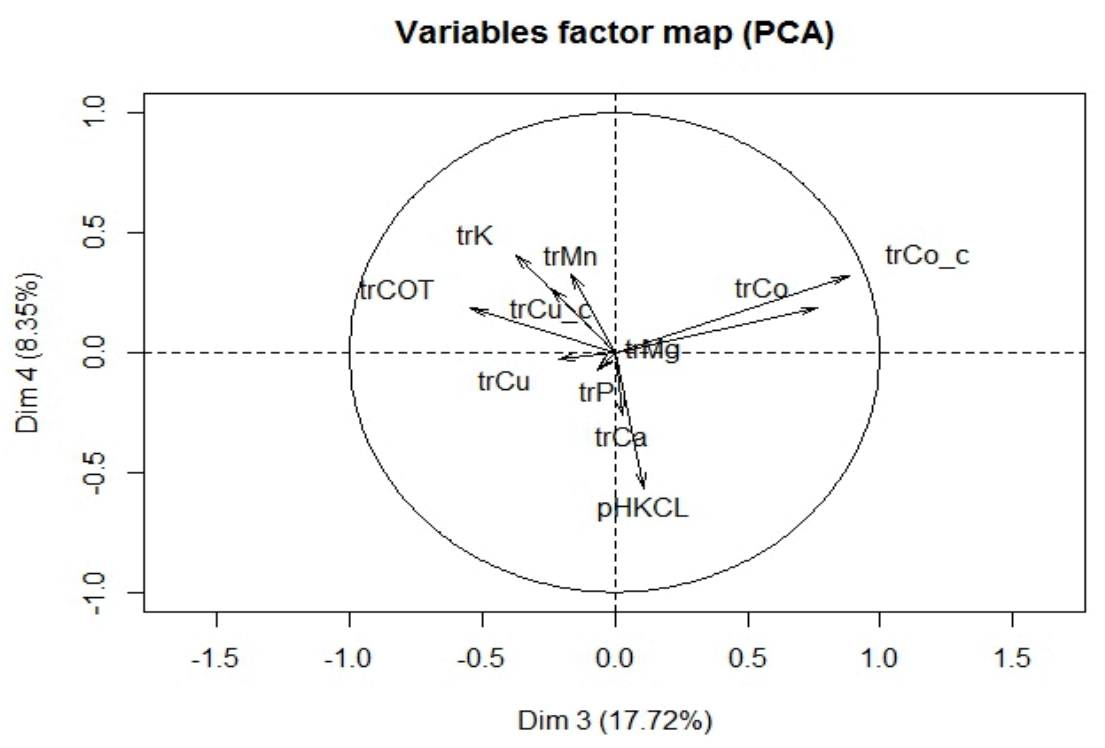

Figure 3: Principal component analysis (PCA) of the soil chemical characteristics (transformed data). Unrotated factors.

\section{Short-distance transitions between vegetation units}

The chemical properties of soils sampled in the various transects are summarized in table 3 . Each transect should be analyzed for itself first.

The transect Fu3T on the small flat summit of Fungurume 3 concerned the transition between a rocky steppic savanna and a natural sward with Xerophyta sp. (Table 1). Each vegetation unit is associated to a different rock outcrop, RSC and RSF respectively. The results (Table 3) show that average soil properties are clearly different between these two units as pH, TOC and every element content are higher on the RSF. Only the Co content difference, when expressed in log is at the limit of the significance $(p=0.051)$. The most significant differences between the two vegetation units are due to $\mathrm{Cu}$ content but at this stage none of the other elements/properties could be dismissed of being a factor of differenciation.

In the transect Fu5T1, across the slope of Fungurume 5, three vegetation units were sampled from the natural sward on RAT, contaminated by colluviating particles from the upslope RSF, to a steppic savanna and a grove with small trees of Uapaca robynsii. Both savanna and grove were on slopes over SDB shales. Excepted $\mathrm{K}$ and Fe contents, every soil properties showed significant differences beween at least two vegetation units. The $\mathrm{C}$ and I units were developped on the same type of rocks, that is SDB, and the B unit on RAT. The total Al content confirmed the influence of lithology on soil properties (Table 3 ) as Al in soil over RAT is almost 1/3 lower than over SDB. The B unit is clearly differing from the other units by chemical properties as TOC, $\mathrm{P}, \mathrm{Cu}$ and Co were far higher than in the two other vegetation units (Figure 4). Regarding the differences between C and I units, it appeared that they were significant for $\mathrm{pH}, \mathrm{Mg}$ and $\mathrm{Ca}$ higher in the I unit, as well as for $\mathrm{Cu}_{\mathrm{CaCl2}}$, lower in I unit. The difference for $\mathrm{Cu}_{\mathrm{CaCl} 2}$ and not for the other $\mathrm{Cu}$ content may be linked to $\mathrm{pH}$ which 
is less acidic under the Uapaca grove. Excepted for $\mathrm{pH}, \mathrm{P}, \mathrm{Al}$ and $\mathrm{Fe}$ content, the $\mathrm{C}$ unit seemed as a transition between sward and grove.

The transect Fu5T2 in the upper part of the slope on the RSF/RAT boundary crossed three vegetation units along a supposed colluviation gradient. Significant differences between the various vegetation units were found for $\mathrm{pH}, \mathrm{Mg}$ and $\mathrm{Ca}$ lower in central sward (Table 3), for $\mathrm{P}, \mathrm{Cu}$ and Co lower in the steppic savanna and for $\mathrm{Al}$ and $\mathrm{Fe}$, lower in the Xerophyta sward on RSF, compared to RAT. As a general rule, the level of $\mathrm{p}$-values was higher than for the two previous transects and no difference was significant for TOC, $\mathrm{K}$ and total $\mathrm{Cu}$, Co and $\mathrm{Mn}$. This should be related to the longitudinal nature of the transect as can be seen in figure 4 . However, the $\mathrm{Cu}_{\mathrm{CaCl} 2}$ content appeared to differentiate significantly the three vegetation units because it reflects both the influence of total $\mathrm{Cu}$ and acidity level. There is in this transect evidence of gradual transition between units rather than abrupt changes.

The Fungurume 8 transects were both perpendicular to northern slope and installed on one given rock type, RAT for Fu8T1 and footslope colluvium for Fu8T2. The Fu8T1 was a short transect across two steppic savanna surrounding a sward developed on an area affected by ore-digging works. Few significant differences between the three vegetation units were found. As indicated by $\mathrm{Al}$ and $\mathrm{Fe}$ content, the lithology of the parent material was rather homogenous. The TOC, P, total $\mathrm{Cu}$ and $\mathrm{Mn}$, $\mathrm{Cu}_{\mathrm{EDTA}}$ and $\mathrm{Co}_{\mathrm{CaCl2}}$ contents were higher in the central sward compared to steppic savannas, and the p-values were generally rather high. It should be noted that the variability of soil properties in the sward was big, probably due to the artificial and chaotic nature of backfill disposal. This high variability hindered the ANOVA and Tukey tests, although the average values of some soil properties might appear as very different according to vegetation units. We can also notice that there were no differences between recently-burned and unburned steppic savannas.

In Fu8T2 transect located at the foot of Fungurume 8, four vegetation units were crossed, with two dembo steppic savannas alternating with a sward and a grove. No significant differences were found for TOC and total $\mathrm{Al}$ contents. The $\mathrm{pH}$ were found lower in the Di unit. The nutrient status was clearly higher in the Uapaca grove and lower in the sward, to the exception of P. The Cu and Co content were the highest in the sward soil and the lowest under the Uapaca grove. The burned (Di) and unburned (D) steppic savannas should be considered as different vegetation units for $\mathrm{pH}_{\mathrm{KCl}}$ and total Fe only (Table 3). Regarding $\mathrm{pH}$, it is not possible to evaluate whether the differences are due to effect of fire but the observations are in contradiction with the usually admitted rise of $\mathrm{pH}$ after burning. Regarding the other chemical properties, they showed intermediate levels between sward and grove and the transition with sward appeared more abrupt than with the grove (Figure 4).

Table 3. Chemical characteristics of topsoil under vegetation units across the transects on three metalliferous hills of the Tenke Fungurume complex (means \pm standard deviations) and p-values associated to ANOVA. (continued). 
Factors of Variation of Soil Chemical Properties in Metalliferous Ecosystems ...

\begin{tabular}{|c|c|c|c|c|c|c|c|c|c|}
\hline \multirow{2}{*}{$\begin{array}{l}\text { Soil } \\
\text { parameter }\end{array}$} & \multicolumn{3}{|l|}{ Fu8T1 } & \multirow[t]{2}{*}{$\mathrm{p}$} & \multicolumn{4}{|l|}{ Fu8T2 } & \multirow[t]{2}{*}{$\mathrm{p}$} \\
\hline & $\mathrm{Ci}(\mathrm{n}=3)$ & $B(n=3)$ & $C(n=3)$ & & $\mathrm{D}(\mathrm{n}=3)$ & $B(n=3)$ & Di $(n=3)$ & I $(n=3)$ & \\
\hline TOC (\%) & $3.3 \pm 0.4^{\mathrm{ab}}$ & $3.5 \pm 0.16^{\mathrm{a}}$ & $2.8 \pm 0.06^{\mathrm{b}}$ & 0.035 & $3.7 \pm 0.28$ & $2.8 \pm 0.45$ & $2.65 \pm 0.1$ & $2.96 \pm 0.47$ & 0.070 \\
\hline $\mathrm{pH}_{\mathrm{H} 2 \mathrm{O}}$ & $5.4 \pm 0.08$ & $5.6 \pm 0.4$ & $5.8 \pm 0.05$ & 0.371 & $5.4 \pm 0.14^{\mathrm{ab}}$ & $5.2 \pm 0.14^{\mathrm{ab}}$ & $5.2 \pm 0.02^{\mathrm{b}}$ & $5.7 \pm 0.21^{\mathrm{a}}$ & 0.015 \\
\hline $\begin{array}{l}\mathrm{pH}_{\mathrm{KCl}} \\
\mathrm{K}(\mathrm{mg} /\end{array}$ & $5.1 \pm 0.14$ & $5.6 \pm 0.4$ & $5.4 \pm 0.26$ & 0.259 & $5.2 \pm 0.01^{\mathrm{a}}$ & $4.99 \pm 0.21^{\mathrm{ab}}$ & $4.7 \pm 0.1^{b}$ & $5.14 \pm 0.18^{\mathrm{a}}$ & 0.011 \\
\hline $100 \mathrm{~g})$ & $12 \pm 2.9^{\mathrm{a}}$ & $6.2 \pm 1.6^{\mathrm{a}}$ & $13 \pm 4.4^{\mathrm{a}}$ & 0.048 & $12 \pm 1.45^{\mathrm{b}}$ & $6.1 \pm 0.34^{\mathrm{c}}$ & $18 \pm 0.99^{\mathrm{ab}}$ & $21 \pm 5.2^{\mathrm{a}}$ & 0.000 \\
\hline $\begin{array}{l}\mathrm{Mg}(\mathrm{mg} \\
100 \mathrm{~g})\end{array}$ & $18 \pm 4.3$ & $11 \pm 7.8$ & 1 & 280 & $20 \pm 5.3^{b}$ & $6^{\mathrm{C}}$ & $25 \pm 5.1^{\mathrm{ab}}$ & $52=$ & 0.000 \\
\hline Ca (mg/ & & & & & & & & & \\
\hline $\begin{array}{l}100 \mathrm{~g}) \\
\mathrm{P}(\mathrm{mg} /\end{array}$ & $53 \pm 11$ & $58 \pm 62$ & $50 \pm 16$ & 0.859 & $71 \pm 28^{\mathrm{a}}$ & $20 \pm 7.9^{b}$ & $32 \pm 3.01^{\mathrm{ab}}$ & $73 \pm 22^{a}$ & 0.002 \\
\hline $100 \mathrm{~g})$ & $1.1 \pm 0.24^{\mathrm{b}}$ & $7.7 \pm 5.0^{\mathrm{a}}$ & $1.1 \pm 0.1^{\mathrm{b}}$ & 0.010 & $1.15 \pm 0.55^{\mathrm{ab}}$ & $1.74 \pm 0.9^{\mathrm{a}}$ & $0.63 \pm 0.06^{\mathrm{ab}}$ & $0.6 \pm 0.2^{b}$ & 0.026 \\
\hline $\begin{array}{l}\mathrm{Cu}(\mathrm{mg} / \\
\mathrm{kg})\end{array}$ & $752 \pm 164^{b}$ & $10642 \pm 8392^{\mathrm{a}}$ & $1403 \pm 1188^{b}$ & 0.020 & $1409 \pm 440^{\mathrm{b}}$ & $4765 \pm 2298^{\mathrm{a}}$ & $1472 \pm 302^{b}$ & $664 \pm 44^{\mathrm{C}}$ & 0.000 \\
\hline $\begin{array}{l}\mathrm{Cu}_{\text {EDTA }} \\
(\mathrm{mg} / \mathrm{g})\end{array}$ & $263 \pm 62^{b}$ & $3188 \pm 2287^{a}$ & $498 \pm 494^{\mathrm{b}}$ & 0.031 & $638 \pm 268^{a b}$ & $1958 \pm 1358^{a}$ & $343 \pm 90^{\mathrm{bc}}$ & $144 \pm 13^{\mathrm{b}}$ & 0.001 \\
\hline $\begin{array}{l}\mathrm{Cu}_{\mathrm{CaCl} 2} \\
(\mathrm{mg} / \mathrm{kg})\end{array}$ & $1.6 \pm 0.9^{\mathrm{a}}$ & $86 \pm 73^{a}$ & $1.8 \pm 1.4^{\mathrm{a}}$ & 0.058 & $5.3 \pm 4.6^{\mathrm{bc}}$ & $95 \pm 49^{\mathrm{a}}$ & $7.8 \pm 4.4^{b}$ & $0.62 \pm 0.34^{\mathrm{C}}$ & 0.001 \\
\hline $\begin{array}{l}\text { Co (mg/ } \\
\mathrm{kg})\end{array}$ & $1101 \pm 36^{b}$ & $1675 \pm 271$ & $994 \pm 398$ & 0.150 & $473 \pm 160^{\mathrm{b}}$ & $972 \pm 220^{\mathrm{a}}$ & $373 \pm 108^{b}$ & $330 \pm 30^{\mathrm{b}}$ & 0.003 \\
\hline $\begin{array}{l}\mathrm{Co}_{\mathrm{CaCl} 2} \\
(\mathrm{mg} / \mathrm{kg})\end{array}$ & $22 \pm 4.1^{\mathrm{ab}}$ & $51 \pm 37^{\mathrm{a}}$ & $12 \pm 2.8^{\mathrm{b}}$ & 0.053 & $21 \pm 11^{\mathrm{ab}}$ & $39 \pm 7.1^{\mathrm{a}}$ & $5.6 \pm 0.8^{\mathrm{bc}}$ & $4.63 \pm 3.8^{\mathrm{C}}$ & 0.001 \\
\hline $\begin{array}{l}\mathrm{Mn}(\mathrm{mg} / \\
\mathrm{kg})\end{array}$ & $534 \pm 107^{a b}$ & $703 \pm 52^{\mathrm{a}}$ & $399 \pm 116^{b}$ & 0.022 & $728 \pm 190$ & $728 \pm 108$ & $789 \pm 161$ & $591 \pm 49$ & 0.400 \\
\hline $\mathrm{Al}(\%)$ & $3.3 \pm 0.6$ & $3.1 \pm 0.6$ & $2.4 \pm 0.8$ & 0.318 & $4.9 \pm 0.41$ & $4,6 \pm 0.46$ & $5.12 \pm 0.34$ & $4.13 \pm 0.29$ & 0.051 \\
\hline $\mathrm{Fe}(\%)$ & $2.21 \pm 0.3$ & $3.1 \pm 0.8$ & $2.5 \pm 0.5$ & 0.260 & $2.9 \pm 0.2^{\mathrm{b}}$ & $3,6 \pm 0.48^{b}$ & $4.49 \pm 0.19^{\mathrm{a}}$ & $3.62 \pm 0.08^{b}$ & 0.001 \\
\hline
\end{tabular}

ANOVA were performed on transformed data except for $\mathrm{pH}, \mathrm{Mn}, \mathrm{Al}$ and $\mathrm{Fe}$. Means that do not share a letter are significantly different after Tukey at 95\%.

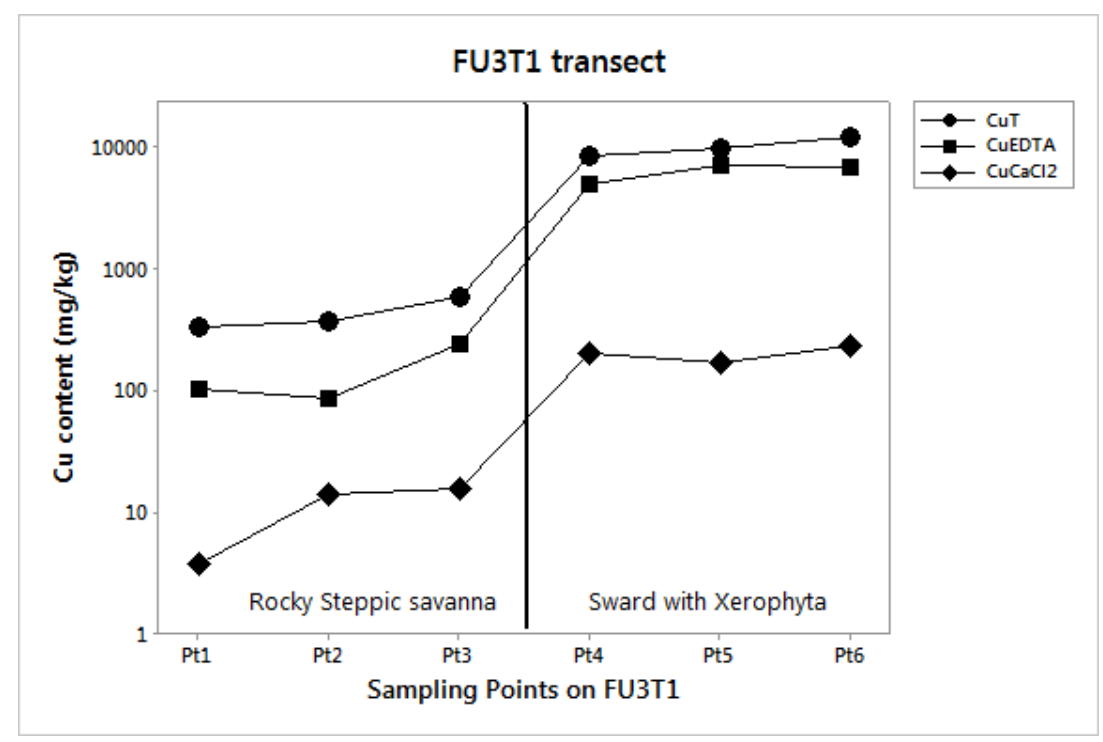



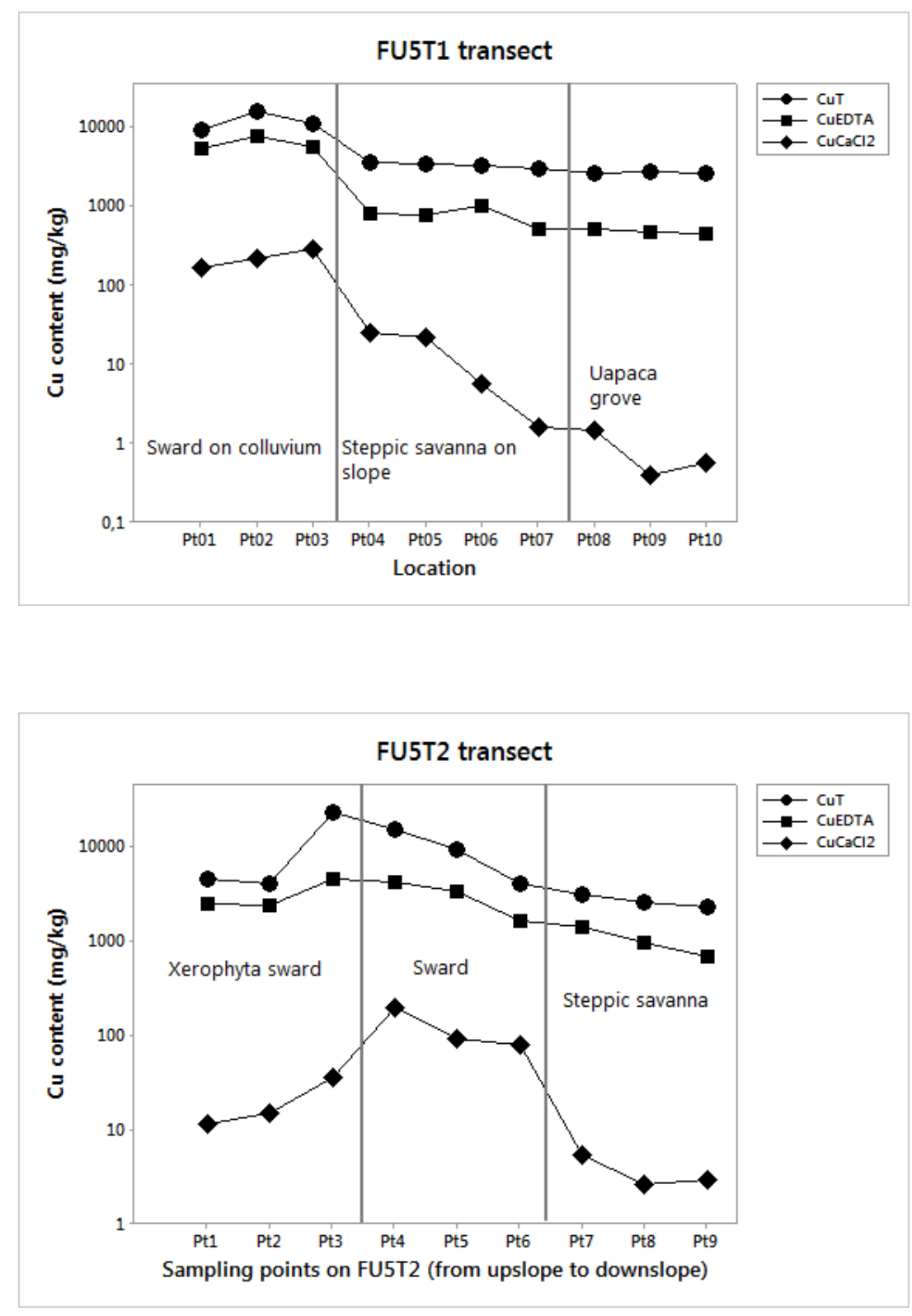

Figure 4: Evolution of $\mathrm{Cu}$ content along the transects: Fu3T1, Fu5T1, and Fu5T2.

The analysis of semivariance is summarized in table 4. Transitions were evaluated for all neighbouring units and also specifically for borders between swards (B, E) and steppic savannas (A, C, D). The variation between the hills is not taken into consideration in the semivariance. The global variance is largely bigger than semi-variance for $\mathrm{Co}, \mathrm{Mn}, \mathrm{Al}$ and Fe content (Table 4), which expresses significant differences between sites.

Regarding transitions, semivariances between two neighbour vegetation units are 2 to 6 times higher than semivariances within vegetation units, to the exception of Co content for which both semivariances are similar. The less pronounced differences concern the total $\mathrm{Al}, \mathrm{Fe}$ and $\mathrm{Mn}$ which reflect the nature of the soil parent material and variations occur mainly between siliceous rocks (RSC) and rocks with clay minerals (RSF, RAT, SDB, colluviums). The pH and nutrient status vary 
Factors of Variation of Soil Chemical Properties in Metalliferous Ecosystems ...

strongly between two vegetation units, mainly between the Uapaca groves (I) and steppic savannas (C, D) and with less strength between swards (B, E) and neighbours. The most abrupt transitions between vegetation units is due to $\mathrm{Cu}$ content and organic matter and they concern dominantly the swards as can be seen by comparing the specific g-swards given at table 4 .

Table 4. Analysis of transitions between adjacent vegetation units: Global variance $\left(\sigma^{2}\right)$, proportion of variance in the variation between studied vegetation units $\left(\% \sigma^{2}\right)$, residual mean square (MSr) of ANOVA, semivariances $(\gamma)$ of neighbours points between two adjacent units and within one unit.

\begin{tabular}{|c|c|c|c|c|c|c|c|c|}
\hline \multirow[t]{2}{*}{ Variable } & \multirow[t]{2}{*}{ Unit } & \multirow{2}{*}{$\begin{array}{l}\text { Variance } \\
\sigma^{2}\end{array}$} & \multicolumn{2}{|c|}{ ANOVA } & \multicolumn{2}{|c|}{$\gamma$ - all units } & \multicolumn{2}{|c|}{$\gamma$ - swards } \\
\hline & & & $\% \sigma^{2}$ & $\mathrm{MSr}$ & between & within & between & within \\
\hline TOC & $\mathrm{g} / 100 \mathrm{~g}$ & 0,1622 & 74 & 0,0427 & 0,1549 & 0,0284 & 0,1487 & 0,0224 \\
\hline $\mathrm{pH}_{\mathrm{H} 2 \mathrm{O}}$ & & 0,2144 & 72 & 0,0609 & 0,2475 & 0,0475 & 0,1400 & 0,0524 \\
\hline $\mathrm{pH}_{\mathrm{KCl}}$ & & 0,2591 & 68 & 0,0833 & 0,2473 & 0,0626 & 0,1285 & 0,0672 \\
\hline K & $\mathrm{mg} / 100 \mathrm{~g}$ & 0,0454 & 67 & 0,0149 & 0,0456 & 0,0107 & 0,0550 & 0,0118 \\
\hline $\mathrm{Mg}$ & & 0,1538 & 81 & 0,0297 & 0,1180 & 0,0259 & 0,1155 & 0,0288 \\
\hline $\mathrm{Ca}$ & & 0,1400 & 66 & 0,0477 & 0,1535 & 0,0440 & 0,1353 & 0,0497 \\
\hline $\mathrm{P}$ & & 0,2526 & 75 & 0,0630 & 0,2041 & 0,0446 & 0,2184 & 0,0473 \\
\hline $\mathrm{Cu}$ & $\mathrm{mg} / \mathrm{kg}$ & 0,2348 & 80 & 0,0459 & 0,2578 & 0,0483 & 0,3182 & 0,0553 \\
\hline $\mathrm{Cu}_{\mathrm{EDTA}}$ & & 0,3170 & 85 & 0,0488 & 0,2975 & 0,0498 & 0,3685 & 0,0570 \\
\hline $\mathrm{Cu}_{\mathrm{CaCl} 2}$ & & 0,8220 & 79 & 0,1694 & 0,7019 & 0,1743 & 0,8578 & 0,1834 \\
\hline Co & & 0,1256 & 57 & 0,0538 & 0,0501 & 0,0406 & 0,0602 & 0,0465 \\
\hline $\mathrm{Co}_{\mathrm{CaCl} 2}$ & & 0,2397 & 73 & 0,0642 & 0,1259 & 0,0887 & 0,1335 & 0,0526 \\
\hline $\mathrm{Mn}$ & & 99930 & 85 & 14807 & 28984 & 11726 & 24970 & 12823 \\
\hline $\mathrm{Al}$ & $\mathrm{g} / 100 \mathrm{~g}$ & 2,127 & 78 & 0,4686 & 0,3923 & 0,1891 & 0,4226 & 0,1892 \\
\hline $\mathrm{Fe}$ & & 1,135 & 81 & 0,2139 & 0,2734 & 0,1212 & 0,3128 & 0,1380 \\
\hline
\end{tabular}

\section{Discussion}

\section{Variability of soil properties in metalliferous ecosystems}

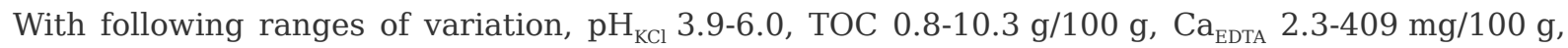
$\mathrm{Mg}_{\text {EDTA }} 1.5-73 \mathrm{mg} / 100 \mathrm{~g}, \mathrm{~K}_{\text {EDTA }} 2.7-26 \mathrm{mg} / 100 \mathrm{~g}, \mathrm{P}_{\text {EDTA }} 0.3-31 \mathrm{mg} / 100 \mathrm{~g}, \mathrm{Cu}_{\text {EDTA }} 25-10,000 \mathrm{mg} / \mathrm{kg}$, $\mathrm{Co}_{\text {EDTA }}$ 1.5-114 mg/kg, our study concerned soils similar to those of Faucon et al. (14), Saad et al. (43), Séleck et al. (44), Ilunga wa Ilunga et al. (19) and Boisson et al. (3, 4). Within these works, only Fu3 and Fu5 $(3,44)$ were common to our study. This is a first indication that the entire soil conditions at regional scale (> 20 different hills) can be encountered within smaller areas. Ilunga wa Ilunga et al. (19) also found broad range of soil properties within one single-site (Kinsevere) which is not included within the Tenke-Fungurume complex.

The multivariate analysis has allowed to identify four major factors of soil variation. Factors 1 and 3 are linked to soil contamination by $\mathrm{Cu}$ and $\mathrm{Co}$, respectively. The two other factors are driven by major nutrient and $\mathrm{pH}_{\mathrm{KCl}}$ levels. Investigating the relationships between the floristic composition of vegetation quadrats and soil properties, Saad et al. (43) found that $40 \%$ of the floristic variability was correlated to the first two soil factors which were a trace metal contamination factor $(\mathrm{Cu}, \mathrm{Co}$, 
$\mathrm{Cd}, \mathrm{Pb}$ and $\mathrm{Zn}$ ) on the one side and a gradient of total elements linked to clay content ( $\mathrm{Mg}, \mathrm{Fe}$ ) on the other side. In our study, we can estimate that respectively 44, 21, 2.5 and $10 \%$ of the variance of factors 1 to 4 are linked with differences of vegetation units, based on one-way anova.

Regarding the variability of single soil properties associated with the vegetation units (Table 2 and Figure 2), a significant proportion of residual variance is not directly associated to discrimination between the four vegetation units, especially for acido-basic and organic status and other potential contaminants than $\mathrm{Cu}$ ( $\mathrm{Co}$ and $\mathrm{Mn}$ ). This suggests that there is a natural variation within all vegetation units and that soil chemical properties can overlap. The question of the relevance of the vegetation units used might be raised. We used the same as Saad et al. (43) plus the dembo steppic savanna. Indeed, Saad et al. (43) defined 3 plant communities by Detrented Correspondance Analysis (DCA) of 145 taxa observed in 62 plots over 6 different hills from Tenke-Fungurume. Later, on three other hills, Seleck et al. (44) proposed 2 partitions of the slope vegetation (no rocky steppe studied), one in two groups and another one in seven groups. The first classification distinguishes only "steppes" and "steppic savannas", which are equivalent to groups B (what we called sward) and $\mathrm{C}$ in our study. The distinction of 7 communities within the latter two was linked to differences between the study sites, which does not question our classification. From Kinsevere copper outcrop, Ilunga wa Ilunga et al. (19) used an unweighted pair group method with arithmetic mean (UPGMA) to classify their plant species survey into 5 groups, of which two were swards and three were steppic savannas. Results also showed that differenciating the steppic savannas according to their position within the relief (Dembo versus slope) was consistent. Other approaches were used by Boisson et al. (3) or Delhaye et al. (8), which worked over slope gradients rather than vegetation units to define edaphic niche species or community variation of plant traits, respectively. However, their results also suggest that there is a significant variability in both the spatial distribution of soil properties at short distances (decametric scale) and of the plant performance (niche and traits).

The sites are significantly different for soil TOC, $\mathrm{Cu}$ and Co contents (table 2). SHC appears as specifically rich in organic matter and in $\mathrm{Cu}$, which is partly due to the highest proportion of swards in the sample (50\%) compared to Fu1, Fu3 and Fu8 (25\%) and especially Fu9 (no sward). It is also interesting to notice that the sites which are richer in Co (Fu3 and Fu8) are not the same as for $\mathrm{Cu}$ content. This should be attributed to differences in the $\mathrm{Cu}$-Co mineralisation processes between the hills (15). The analysis of transects on Fu3, Fu5 and Fu8 confirmed the importance of site effect for $\mathrm{Co}$ but not for $\mathrm{Cu}$ and TOC. Significant differences were found for TOC in the steppic savannas with less organic matter in the topsoil in Fu8 and Fu9 compared to the others. The toxicity of the metals for soil microorganisms cannot be argued to differentiate between sites. The accumulation of organic matter can be linked to the vegetation development and inputs made through the death of leaves and roots wich are proportionnal to the biomass on the one side and to the passage of fires during the dry seasons. Different history of fire burning might explain the variations observed.

Steppic savannas are located on slopes and foot slopes on RAT rock. The soil enrichment in $\mathrm{Cu}$ or Co may be due to inheritage and we should question about the natural variability of parent material from one side to another. Or the top soil may be contaminated by surface or subsurface transportation of metals and the characteristics of the relief (intensity and length of the slope, distance to the summit, microrelief...) and the vegetation cover should be considered as factor of variability. The vegetation units are heterogeneous $(3,8)$ and affected by the occurrence of the natural contamination at the bottom of RSF outcrop and gradual decrease of contamination with the topography. The analysis of transect Fu5T2 (Table 3 and Figure 4) suggests that there might effectively be surface transportation from RSF outcrops to soils downstream in the upper part of 
the slope as suggested by previous authors $(3,4,8,9,28,30,31)$. However, the results found by Kaya Muyumba et al (25) from the study of 42 soil profiles in Tenke-Fungurume hills show that most subsurface horizons are also contaminated and evidences of topsoil contamination by surface processes were only present for some swards. This suggests us that the main source of variability for soil properties within the other vegetation units should be linked to inheritage rather than surface transportation.

\section{Metric variations of soil chemical characteristics in transects}

As a general rule, the swards (B, E) show higher levels of TOC, $\mathrm{P}, \mathrm{Cu}$ and Co contents and lower levels in nutrients than the steppic savannas. At the opposite, the groves (I) are characterized by more favourable $\mathrm{pH}$ and nutrient conditions. The steppic savannas (A, C, D) present intermediate soil chemical properties. Regarding the transitions between the vegetation units, the transects perpendicular to the slopes show that they were abrupt between swards and steppic savannas and more gradual between the latter and the Uapaca groves. Soil properties can be affected by burning of vegetation but effects are not completely understood (40). We found no effect (Fu8T1) or lower $\mathrm{pH}$ in burned steppic savanna compared to unburned, which does not seem to be an expected result of burning (40). Moreover, it is not realistic that the burning of the vegetation could affect the soil iron content. Hence, we cannot consider that burning is a real factor of variation in the studied transects.

Significant differences of soil properties from successive vegetation units located are observed along the mini transects. The transitions are abrupt between swards and steppic savannas for TOC, $\mathrm{Cu}$ and nutrient (K, P, Mg) content (Table 4). However, among these elements only the $\mathrm{Cu}$ content appears to be a limitation factor for vegetation due to phytotoxicity. Nutrients are clearly linked to geochemical composition of soil parent material and swards present higher content in $\mathrm{P}$ due to presence of phosphates (pseudomalachite, $\mathrm{Cu}_{5}\left(\mathrm{PO}_{4}\right)_{2}(\mathrm{OH})_{4}$ ) in RSF and SDB (41). Higher TOC content can be associated to organic matter accumulation through reduced microbial activity or increased root development. Soil P and TOC levels cannot however be considered as limiting factors but as correlated variables. The transition between steppic savannas and Uapaca groves were gradual (Figure 4). However, the only common factor between both studied transitions (Fu5T1 and Fu8T2) was the increase of $\mathrm{pH}$ and decrease of $\mathrm{Cu}_{\mathrm{Cacl}}$ from steppic savanna to grove. The levels of $\mathrm{Mg}$ and $\mathrm{Ca}$ also tend to be higher under the grove. At this point, we don't know if the $\mathrm{pH}$ and nutrient status are the result, the factor or only correlated variables of the vegetation differentiation but the reduction of toxicity seems to be a crucial factor (7, 10, 11, 32, 41, 42, 50). Most studies so far used total $\mathrm{Cu}$ or $\mathrm{Cu}_{\mathrm{EDTA}}$ to analyse soil-vegetation relationships in the metalliferousecosystems of Katanga. However, it seems from our results that the use of $\mathrm{Cu}_{\mathrm{CaCl} 2}$ might be better to discriminate vegetation units because it is linked to a potential reserve (total $\mathrm{Cu}$ ) and effective conditions of solubility such as acido-basic status (32). Assessment of chemical fractionation by geochemical modelling is another alternative (41).

\section{Conclusion}

Our study aimed at deepen our understanding of relationships between soil properties and vegetation distribution in copper/cobaltiferous ecosystems of Tenke-Fungurme. Physiognomic changes of vegetation observed in Katanga copper hills were first considered as the expression of the variation of the soil $\mathrm{Cu}$ and $\mathrm{Co}$ content. However, if soluble and available forms of $\mathrm{Cu}$ contribute to exert 
a strong selection pressure for plants due to phytotoxicity, other properties, such as topographic position, soil parent material, soil nutrient status, soil depth... also vary within the landscape.

Four factors of variation of soil properties were summarized by multivariate analysis, two are linked to $\mathrm{Cu}$ or $\mathrm{Co}$ contamination, one to nutrient status and one to $\mathrm{pH}_{\mathrm{KCl}}$. The four of them can be linked to lithology and they contribute to explain a significant part of the distribution of vegetation units. However, the residual variability of soil properties within each vegetation unit remains significant.

The lithological factor is important in hilly landscapes even under tropical climate because soils are rejuvenated by erosion processes. The distribution of swards and various steppic savannas in the landscape is clearly the result of an adaptation of species to the phytotoxic effect of metals originating from rocks. Our result suggest that the variation of soil properties which is observed within the various vegetation units should partially be attributed to differences of geochemical composition of rocks between sites for $\mathrm{Cu}$ and Co contents. These differences however do not concern the $\mathrm{pH}$ nor the nutrient status for which the main source of variability is to be found inside each metalliferous hill. The distribution of $\mathrm{pH}_{\mathrm{KCl}}$ and nutrients in the hill follows the mineralogical composition of rocks: acidic reaction and low nutrient content over siliceous rocks at the top, less acidic reaction and enrichment in $\mathrm{P}$ over mineralized outcrops, intermediate soil reaction, lower $\mathrm{P}$ content and higher $\mathrm{K}$ and $\mathrm{Mg}$ content over RAT. The soil contamination in $\mathrm{Cu}$ and $\mathrm{Co}$ also originates from rock weathering and we think that besides the above-mentioned site effect and topographic distribution of the rocks, the variability of soil properties within one vegetation unit may be due to spatial variability of soil parent material and not only due to erosion processes.

A deeper insight was put on the transition between vegetation units at metric scale, which had never been done so far in the copper ecosystems of Katanga. The abrupt changes of vegetation units which were clearly identified on the field were all truly explained by the variations of one or more properties linked to lithology. The key point seem to be the Cu-phytotoxicity which depends on total reserve in $\mathrm{Cu}$ and acidity level and was estimated by $0,01 \mathrm{~N} \mathrm{CaCl}_{2}$ extraction in our study.

\section{Acknowledgments}

This study was financially supported by Belgian Technical Cooperation (BTC). Tenke Fungurume Mining s.p.r.l provided authorizations and logistic support to sample soil and vegetal material.

\section{Bibliography}

(1) Baker A.J.M., Ernst W.H., van der Ent A., Malaisse F. \& Ginocchio R., 2010, Metallophytes: the unique biological resource, its ecology and conservational status in Europe, central Africa and Latin America. In Batty \& Haalberg Eds, Ecol. Industrial Pollution, Cambridge University Press: 7-40.

(2) Baker A.J.M., 1981, Accumulators and excluders-Strategies in the response of plants to heavy metals. J. Plant Nutr., 3, 643-654.

(3) Boisson S., Monty A., Lebrun J., Séleck M. \& Mahy G., 2016, Edaphic niches of metallophytes from southeastern Democratic Republic of Congo: Implications for post-mining restoration. $J$. Nature Conserv., 33, 18-24.

(4) Boisson S., Faucon M.-P., Le Stradic S., Lange B., Verbruggen N., Garin O., Tshomba Wetshy A., 
Factors of Variation of Soil Chemical Properties in Metalliferous Ecosystems ...

Seleck M., Masengo Kalengo W., Ngoy Shutcha M. \& Mahy G., 2017, Specialized edaphic niches of threatened copper endemic plant species in the D.R. Congo: implications for ex-situ conservation. Plant Soil, 413, 261-273.

(5) Brooks R.R. \& Malaisse F., 1990, Metal-enriched sites in south central Africa. In Shaw J.A. (ed) Heavy metal tolerance in plants: evolutionary aspects, 53-73. New York. CRC Press.

(6) Brun L.A., Maillet J., Richarte J., Herrmann P. \& Remy J.C., 1998, Relationships between extractable copper, soil properties and copper uptake by wild plants in vineyard soils. Environ. Pollution, 102, 151-161.

(7) Chipeng F., Hermans C., Colinet G., Faucon M.-P., Ngongo M., Meerts P. \& Verbruggen N., 2010, Copper tolerance in the cuprophyte Haumaniastrum katangense (S. Moore) P.A. Duvign. \& Plancke. Plant Soil, 328, 235-244.

(8) Delhaye G., Violle C., Seleck M., Ilunga wa Ilunga E., Daubie I., Mahy G. \& Meerts P., 2016, Community variation in plant traits along copper and cobalt gradients. J. Vegetation Sc.,27, 854-864.

(9) Duvigneaud P. \& Denayer-De Smet S., 1963, Cuivre et végétation au Katanga. Bull. Soc. Royale Bot. Belgique,96, 92-231.

(10) Faucon M.-P., Chipeng F., Verbruggen N., Mahy G., Colinet G., Shutcha M., Pourret O. \& Meerts P. (2012). Copper tolerance and accumulation in two cuprophytes of South Central Africa: Crepidorhopalon perennis and C. tenuis (Linderniaceae). Environ Exp Bot, 84:11-16.

(11) Faucon M.-P., Colinet G., Mahy G., Ngongo Luhembwe M., Verbruggen N., Meerts P., 2009, Soil influence on $\mathrm{Cu}$ and $\mathrm{Co}$ uptake and plant size in the cuprophytes Crepidorhopalon perennis and $C$. tenuis (Scrophulariaceae) in SC Africa. Plant Soil,317, 201-212.

(12) Faucon M.-P., Le Stradic S., Boisson S., Ilungawa wa Ilunga E., Séleck M., Lange B., Guillaume D., Ngoy Shutcha M., Pourret O., Meerts P. \& Mahy G., 2016, Implication of plant-soil relationships for conservation and restoration of copper-cobalt ecosystems. Plant Soil,403, 1, 153-165.

(13) Faucon M.-P., Meersseman A., Shutcha N.M., Mahy G., Ngongo Luhembwe M., Malaisse F. \& Meerts P., 2010, Copper endemism in the Congolese flora: a database of copper affinity and conservational value of cuprophytes. Plant Ecol. Evolution, 143, 1, 5-18.

(14) Faucon M.-P., Parmentier I., Colinet G., Mahy G., Ngongo Luhembwe M., Meerts P. (2011). May rare metallophytes benefit from disturbed soils following mining activity? The case of the Crepidorhopalon tenuis in Katanga (D.R. Congo). Restoration Ecol., 19, 3, 333-343.

(15) Fay I. \& Barton M.D., 2012, Alteration and ore distribution in the Proterozoic Mines Series, Tenke-Fungurume Cu-Co district, Democratic Republic of Congo. Mineralium Deposita,47, 501-519.

(16) Fernandez-Cornudet C., 2006, Devenir du Zn, Pb et Cd issus de retombées atmosphériques dans les sols, à différentes échelles d'étude. Influence de l'usage des sols sur la distribution et la mobilité des métaux. PhD thesis, INRA Paris Grignon, France.

(17) Houba V.J.G., Novozamsky I., Huybregts A.W.M. \& Van Der Lee J.J., 1986, Comparison of soil extractions by $0.01 \mathrm{M} \mathrm{CaCl}_{2}$, by EUF and by some conventional extraction procedures. Plant 
Soil,96, 433-437.

(18) Ilunga wa Ilunga E., 2014, Les communautés végétales des affleurements de roches métallifères: Une ressource biologique pour la restauration des mines et des sols dégradés par les activités minières dans le Haut Katanga (R.D.Congo).PhD thesis, University of Lubumbashi, DR Congo.

(19) Ilunga wa Ilunga E., Séleck M., Colinet G., Faucon M.-P., Meerts P. \& Mahy G., 2013. Smallscale diversity of plant communities and distribution of species niches on a copper rock outcrop in Upper Katanga, D.R.Congo. Plant Ecol. Evolution, 146, 173-182.

(20) Jacobi C.M., Do Carmo F.F., Vincent R.C. \& Stehmann J.R., 2007, Plant communities on ironstone outcrops: a diverse and endangered Brazilian ecosystem. Biodiversity Conserv., 16, 7 , 2185-2200.

(21) Kabata-pendias A. \& Pendias H., 2001, Trace Elements in Soils and Plants (3 ${ }^{\text {th }}$ ed). CRC Press.

(22) Kampunzu A.B., Cailteux J.L.H., Moine B. \& Loris H.N.B.T., 2005, Geochemical characterisation, provenance, source and depositional environment of "Roches Argilo-Talqueuses" (RAT) and Mines Subgroups sedimentary rocks in the Neoproterozoic Katangan Belt (Congo): Lithostratigraphic implications. J. Afr. Earth Sc., 42, 119-133.

(23) Kataeva M.N., Alexeeva-Popova N.V., Drozdova I.V. \& Beljaeva A.I., 2004, Chemical composition of soils and plant species in the Polar Urals as influenced by rock type. Geoderma,122, 257-268.

(24) Kaya Muyumba D., Liénard A., Mahy G., Ngongo Luhembwe M. \& Colinet G., 2015, Caractérisation des systèmes sols-plantes dans les collines de l'arc cuprifère du Katanga (Synthèse bibliographique). Biotechnol. Agron. Soc. Environ.,19, 2, 204-214

(25) Kaya Muyumba D., Mahy G. \& Colinet G., 2018, Etude de profils de sols dans les écosystèmes métallifères du complexe Tenke-Fungurume. In Bogaert J., Colinet G. \& Mahy G. Ed. Sci., Anthropisation des paysages au Katanga, Presses Agronomiques de Gembloux, Belgique. In Press.

(26) Kopittke P.M., Asher C.J., Blamey F.P., Menzies N.W. (2009). Toxic effects of Cu2+ on growth, nutrition, root morphology, and distribution of $\mathrm{Cu}$ in roots of Sabi grass. Sci. Total Environ.,407,16, 4616-4621.

(27) Lakanen E. \& Erviö R., 1971, A comparison of eight extractants for the determination of plant available micronutrients in soils. Acta Agric. Fennica,123, 223-232.

(28) Leteinturier B., 2002, Evaluation du potential phytocénotique des gisements cuprifères d'Afrique centro-australe en vue de la phytoremédiation de sites pollués par l'activité minière. $\mathrm{PhD}$ thesis. Faculté des Sciences Agronomiques de Gembloux, Belgique.

(29) Liénard A., Brostaux Y. \& Colinet G., 2014, Soil contamination near a former Zn-Pb oretreatment plant: Evaluation of deterministic factors and spatial structures at the landscape scale. J. Geochem. Explor., 147, 107-116.

(30) Malaisse F., Baker A.J.M. \& Ruelle S., 1999, Diversity of plant communities and heavy metal content at Luiswishi copper/cobalt mineralisation, Upper Katanga, Dem. Rep. Congo. Biotechnol. Agron. Soc. Environ.,3, 2, 104-114. 
Factors of Variation of Soil Chemical Properties in Metalliferous Ecosystems ...

(31) Malaisse F., Gregoire J., Morrison R.S., Brooks R.R., Reeves R.D. (1979). Copper and cobalt in vegetation of Fungurume, Shaba Province, Zaire. Oikos,33, 3, 472-478.

(32) McBride M., Sauve S. \& Hendershot W., 1997, Solubility control of Cu, Zn, Cd and Pb in contaminated soils. Eur. J. Soil Sc., 48, 2, 337-346.

(33) Meers E., Du Laing G., Unamuno V., Ruttens A., Vangronsveld J., Tack F.M.G. \& Verloo M.G., 2007, Comparison of cadmium extractability from soils by commonly used single extraction protocols. Geoderma,141, 247-259.

(34) Morrison R.S., Brooks R.R., Reeves R.D., Malaisse F., Horowitz P., Aronson M. \& Merriam G.R., 1981, The diverse chemical forms of heavy metals in tissue extracts of some metallophytes from Shaba Province, Zaire. Phytochemistry,20, 455-458

(35) Morrison R.S., Brooks R.R., Reeves R.D. \& Malaisse F., 1979, Copper and cobalt uptake by metallophytes from Zaïre. Plant Soil,53, 535-539.

(36) Nagagyoti P.C., Lee K.D. \& Sreekanth T.V.M., 2010, Heavy metals, occurrence and toxicity for plants: a review. Environ. Chem. Lett., 8, 199-216.

(37) Naidu R., Kookana R.S., Oliver D.P., Rogers S. \& McLaughlin M.J., 1996, Contaminants and the Soil Environment in the Australasia-Pacific Region. Kluwer Academic Publishers, London.

(38) Orsega E.F., Agnoli F., Cacco G., Delaney E. \& Argese E., 2003, Effects of copper on Sambucus nigra L. seedlings studied by electron paramagnetic resonance and atomic absorption spectroscopies. Chemosphere,53, 3, 263-268.

(39) Peng H., Wang-Müller Q., Witt T., Malaisse F., Küpper H. (2012). Differences in copper accumulation and copper stress between eight populations of Haumaniastrum katangense. Environ. Exper. Bot., 79, 58-65.

(40) Pivello V.R., Oliveras I., Miranda H.S., Haridasan M., Sato M.N. \& Meirelles S.T., 2010, Effect of fires on soil nutrient availability in an open savanna in Central Brazil. Plant Soil, 337, 1, 111-123.

(41) Pourret O., Lange B., Bonhoure J., Colinet G., Decrée S., Mahy G., Seleck M., Shutcha M. \& Faucon M.-P., 2016, Assesment of soil metal distribution and environmental impact of mining in Katanga (Democratic Republic of Congo). Appl. Geochem., 64, 43-55.

(42) Rooney C.P., Zhao F.J. \& McGrath S.P., 2006, Soil factors controlling the expression of copper toxicity to plants in a wide range of European soils. Environ.Toxicol. Chem., 25, 3, 726-732.

(43) Saad L., Parmentier I., Colinet G., Malaisse F., Faucon M.-P., Meerts P. \& Mahy G., 2012, Investigating the vegetation-soil relationships on the copper-cobalt rock outcrops of Katanga (D. R. Congo), an essential step in a biodiversity conservation plan. Restoration Ecol., 20, 405-415.

(44) Séleck M., Bizoux J.-P., Colinet G., Faucon M.-P., Guillaume A., Meerts P., Piqueray J. \& Mahy G., 2013, Chemical soil factors influencing plant assemblages along copper-cobalt gradients: Implications for conservation and restoration. Plant Soil, 373, 455-469.

(45) Sheoran V., Sheoran A.S. \& Poonia P., 2010, Soil reclamation of abandoned mine land by revegetation: a review. International Journal of Soil, Sediment and Water, 3, 2, article 13. 
(46) Ure A.M., Quevauviller P.H., Muntau H., Griepink B. (1993). Speciation of heavy metals in soils and sediments. An account of the improvement and harmonisation of extraction techniques undertaken under the auspices of the BCR of the Commission of the European Communities. Int. J. Environ. Anal. Chem., 51, 135-151.

(47) Vamerali T., Bandiera M. \& Mosca G., 2010, Field crops for phytoremediation of metalcontaminated land. A review. Environ. Chem. Letters, 8, 1, 1-17.

(48) Walkley A. \& Black I.A., 1934), An examination of the Degtjareff method for determining soil organic matter, and a proposed modification of the chromic acid titration method. Soil Sc., 37, 29-38.

(49) Whiting S.N., Reeves R.D., Richards D., Johnson M.S., Cooke J.A., Malaisse F., Paton A., Smith J.A.C., Angle J.S., Chaney R.L., Ginocchio R., Jaffré T., Johns R., McIntyre T., Purvis O.W., Salt D.E., Schat H., Zhao F.J. \& Baker A.J.M., 2004, Research priorities for conservation of metallophyte biodiversity and their potential for restoration and site remediation. Restoration Ecol., 12, 106-116.

(50) Whittaker R.H., 1954, The Ecology of Serpentine Soils. Ecol. Soc. Am., 35, 2, 258-288.

PDF généré automatiquement le 2023-04-26 14:53:51

Url de l'article : https://popups.uliege.be/2295-8010/index.php?id=250 